\title{
ADVERSE FACTORS THAT CAN AFFECT ON THE COURSE OF CHRONIC PARENCHIMATIC PAROTITIS IN CHILDREN
}

DOI: 10.36740/WLek202006118

Pavlo I. Tkachenko, Serhii O. Bilokon, Yuliia V. Popelo, Nataliia M. Lokhmatova, Olha B. Dolenko, Nataliia M. Korotych

UKRAINIAN MEDICAL STOMATOLOGICAL ACADEMY, POLTAVA, UKRAINE

\begin{abstract}
The aim: The study of the presence of disorders in the ante- and postnatal periods of development of children from 2 months to 15 years with chronic parenchimatic parotitis, which may affect its course.

Materials and methods: It has been examined and treated 88 children, aged from 2 months to 15 years with chronic parenchimatic parotitis, and their mothers were interviewed, who indicated the pathological course of pregnancy, childbirth and indicated the type of breastfeeding babbies. The scope of the survey included general, additional methods, consultations by related specialists and statistical processing of results.

Results: 88 children with the exacerbation of chronic parenchimatic parotitis were examined (42 - (47\%) with active course and 46 - (53\%) with inactive). The exacerbation occurred on the background of acute infectious processes or coincided with the exacerbation of one of the chronic diseases. The first manifestations occurred in spring (55\%) and autumn (36\%) periods, $44 \%$ of children were hospitalized with other diagnoses. The presence of pathological conditions during pregnancy and birth defects in their mothers were recorded more often 3,5 and 3,3 times, respectively, compared with control. $70 \%$ of children received mixed and artificial feeding and were more likely to become ill. Conclusions: The severity of clinical manifestations of inflammation and disorders of the general condition depended on the activity of the course of chronic parenchimatic parotitis and were more pronounced when active. During the remission period, no apparent clinical manifestations were detected in $72 \%$ of observations, however, in $28 \%$, the identified signs indicated a latent course, which required additional treatment and rehabilitation measures.
\end{abstract}

KEY WORDS: children, chronic parenchimatic parotitis, adverse factors, clinical signs

Wiad Lek. 2020;73(6):1173-1176

\section{INTRODUCTION}

Children's doctors of all specialties deal with the body of a child that has not yet fully formed, is dynamically changing and improving. As a result of these circumstances, more and more age-old anatomical and physiological features are revealed, which greatly affect the formation and course of all pathological processes in them. Both internal and external factors cause in the body of the child, in essence, reactions due to the state of their functional and morphological maturity and the peculiarity of metabolic processes $[1,2,3,4]$.

Recently, more and more attention is being paid to pregnancy disorders, hereditary diseases and birth defects that can be caused by chromosomal, gene and genomic mutations. It is believed that diseases with hereditary predisposition occur mainly in individuals who have certain genetic disorders and who are realized under the influence of adverse factors. [2,5].

Chronic parenchimatic parotitis (CPP) in children, which account for $87,6 \%$ of all forms of chronic sialadenitis, is not an exception, which a professor Rybalov O.V. (1987) referred to the primary chronic lesion of the parotid gland, because it can be clinically manifest even immediately after the birth of a child. That is, it may be about the possibility of its heredity. For this disease there is a chronic course with frequent recurrence, which worsens the quality of life of the child and adds significant worries to the relatives, who have to spend time for treatment and money for medicines $[6,7,8,9]$.

\section{THE AIM}

The aim of the study was to study the presence of abnormalities in the ante- and postnatal periods of development of children with chronic parenchimatic parotitis, which may affect its course.

\section{MATERIALS AND METHODS}

The reason for writing this work was the examination and treatment of 88 children with CPP from 2 months to 15 years of age and a survey of their mothers who indicated the most important events related to pregnancy, childbirth and the type of breastfeeding. There were 52 boys and 36 girls. The control group consisted of 50 mothers in whom pregnancy and childbirth proceeded physiologically with their children of the same age. The work was carried out in the conditions of the Poltava regional dispensary center for patients with pathology of salivary glands.

Depending on clinical manifestations, data of private and additional methods of research of patients were divided 
into two groups - with active and inactive course. In children with active course, the frequency of exacerbations ranged from 4 to 9 per year, and they were accompanied by pronounced manifestations of inflammatory reaction in the parotid glands and a significant deterioration of general health. The group with inactive course included persons in whom the exacerbation occurred $1-3$ times a year and proceeded without pronounced clinical manifestations and a slight disturbance of the general condition. [2,5,9]

The scope of the studies included general examination methods (medical history, life, visual examination, palpation, determination of peripheral blood cellular composition and general urine analysis) and private (sialometry, sialography, cytological and microbiological examination of paratid secretion) [5,7].

Additional methods of examination and consultation of related specialists were used as needed. Medical-statistical processing of the obtained results was carried out.

\section{RESULTS AND DISCUSSION}

During the exacerbation of CPP, we examined 88 children, accounting for $8 \%$ of the total number of inpatients. Of these, 42 patients (47\%) had an active disease course, and 46 (53\%) were inactive (Fig. 1). From the anamnesis of the disease, it was found that 13 children (15\%) had $7-9$ exacerbations a year, $13-(18 \%)$ had $5-6,12-(14 \%)$ had $4,21-(24 \%))$ at 3 , at $16-(18 \%)$ at 2 and at 18 - once a year (11\%).

The overwhelming number of patients $(67-76 \%)$ turned for help in the first three days from the onset of symptoms of exacerbation in the parotid glands. In 39 cases (44\%), they were referred for hospitalization with other diagnoses. The distribution of patients observed by age and activity is presented in the table. Most often, with initially diagnosed exacerbation in the parotid glands, relatives of children turned with active flow in toddler and preschool age, with inactive in preschool and primary school. The occurrence of the first manifestations of the disease was observed in 48 children (55\%) in spring, in $32-(36 \%)$ in autumn, and in 8 children (9\%) it was observed in other seasons.

Analysis of pregnancy data from mothers of the surveyed children showed that pathological disorders in them were much more common than in the control group and were 62 cases $(70 \%)$, against 5 - (20\%), respectively. In the structure of pathology, anemia was the first place ( 23 cases $-37 \%)$, the second threat of pregnancy failure (16 cases $-26 \%)$, against 4 cases (8\%) in the control group, the third place was occupied by nephropathy of pregnant women ( 12 cases - $19 \%$ ), against 2 - (4\%), on the fourth - toxicosis of the first half of pregnancy (11 cases - $18 \%$, against $2-4 \%$ in the comparison group) (Table I).

The disturbance of childbirth activity was noted in 23 cases (26\%), in the comparison group $4-(8 \%)$. Hypoxia of newborns (21 cases - 48\%) and weakness of childbirth activity ( 23 cases $-43 \%$ ) were most frequently observed, which required delivery of maternity measures.

After the birth of the baby, signs of intrauterine hyp- otrophy were detected in 33 observations (38\%), versus $4-(8 \%)$. With a large body weight (more than $4 \mathrm{~kg}$ ) of children were $21-(24 \%)$, versus 6 - (12\%).

32 children (36\%) received natural feeding for the year, compared to 28 (56\%) in the control group. The number of infants receiving mixed diets from the 1st and 6th months was equal to 15 (17\% each) compared to $4(8 \%)$ in the comparison group. There were 17 children (19\%) against 6 months of age (12\%) and 24 months (27\%), compared to $8-(16 \%)$ of them from month to month. More frequent cases of decreased lactation among mothers with complicated pregnancy and childbirth (49 out of $88-56 \%$ ) should be noted.

Among children who were in mixed and artificial feeding at the age of one month, 35 were often ill with $47-(74 \%)$ versus $18-(36 \%)$. Among children transferred to mixed and artificial feeding after 6 months, patients were often slightly less than 17 out of 47 - (36\%) versus $14-(28 \%)$ in the control group.

In 54 patients $(61 \%)$, out of all 88 , concomitant chronic diseases were revealed, which were distributed as follows: gastrointestinal tract of 13 children (24\%), bronchopulmonary system of 11 children (20\%), ENT pathology revealed in 11 children (20\%), genitourinary system in 10 children (18\%), cardiovascular system in 7 children (12\%), skin disease was found in 2 children (4\%), nervous system diseases in 1 person (2\%). The number of concomitant chronic diseases was predominant in the group of patients with active course of CPP ( 32 children - 59\%). While in the group with inactive course concomitant somatic pathology was detected in 22 children (41\%).

We found that exacerbation of the chronic process in the parotid glands occurred in 33 patients (38\%) against the background of SARS, in $19-(22 \%)$ coincided with the course of acute tonsillitis, in $18-(20 \%)$ occurred on the background of exacerbation of one of the above chronic diseases and in $9-(10 \%)$ it was combined with herpetic stomatitis. In 11 children (12\%) the presence of two nosological forms of somatic diseases was observed and in $8-(9 \%)$ external and internal provoking causal factors could not be determined.

At the time of treatment, during exacerbation of the chronic process in the software, patients complained of pain and swelling in the area of one gland (83 children - 94\%) or two (5 children - 6\%), with a slight restriction of mouth opening followed in 35 children (40\%). In 16 patients (18\%) headache, nausea, salty taste of mouth fluid were noted. The general condition and appetite worsened to a different extent in all children. Body temperature varied between $37-39^{\circ} \mathrm{C}$ in 41 children (47\%), while in the rest $47-(53 \%)$ it remained within the physiological norm.

On external examination, all patients had a swelling in the parotid-chewing area that went beyond the anatomical location of the gland ( 28 patients - 32\%), was limited to the contours of the gland ( 38 patients $-43 \%$ ), or its individual lobes (22 patients $-25 \%$ ).

A sufficient amount of turbid, foamy, viscous mouth fluid was identified in the oral cavity, and the oral mucosa had 


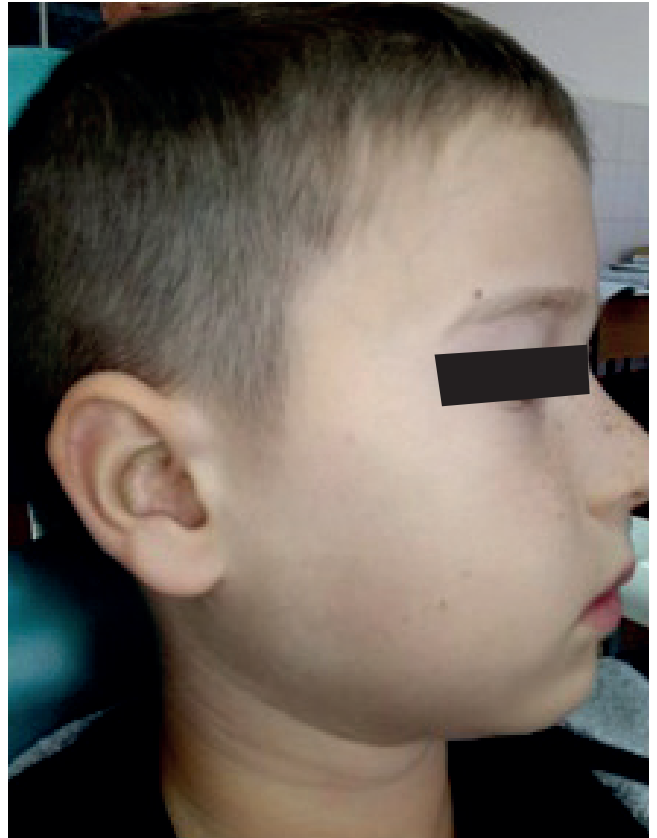

Fig. 1. Facial appearance of the patient $D ., 7$ years old, ambulatory card № 45 . A slight swelling of soft tissues in the area of anatomic projection of the parotid gland is determined. Diagnosis: exacerbation of chronic parenchimatic parotitis on the right, inactive.

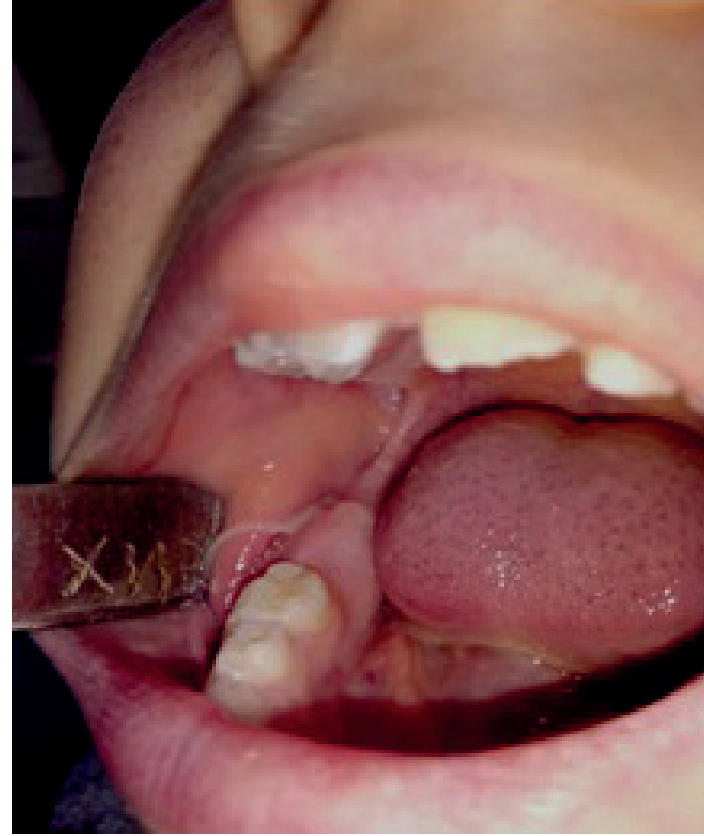

Fig. 2. The appearance of secretions from the parotid gland of the patient M., 6 years old, ambulatory card № 32. Near the mouth of the excretory duct a"protein strand" is defined - the imprint of the main duct with impurities of pus. Diagnosis: exacerbation of chronic parenchimatic parotitis on the right, active course.

Table I. Distribution of patients with chronic parenchimatic parotitis by age and disease activity

\begin{tabular}{|c|c|c|c|c|c|c|c|}
\hline \multirow{3}{*}{ № } & \multirow{3}{*}{ Age groups } & \multicolumn{6}{|c|}{ The course of the disease and the number of patients } \\
\hline & & \multicolumn{2}{|c|}{ Active } & \multicolumn{2}{|c|}{ Inactive } & \multicolumn{2}{|c|}{ Total } \\
\hline & & Number & $\%$ & Number & $\%$ & Number & $\%$ \\
\hline 1 & Breast - from 1 month to a year & 1 & 2 & 1 & 2 & 2 & 2 \\
\hline 2 & Nursery - from 1 to 3 years & 11 & 26 & 6 & 13 & 17 & 19 \\
\hline 3 & Preschool - from 3 to 7 years & 23 & 54 & 22 & 49 & 45 & 51 \\
\hline 4 & Junior school - from 7 to 12 years & 7 & 17 & 15 & 33 & 22 & 25 \\
\hline 5 & The senior school - from 12 to 15 years & 42 & - & 2 & 3 & 2 & 3 \\
\hline 6 & Total & 42 & 100 & 46 & 100 & 88 & 100 \\
\hline
\end{tabular}

pink color in 69 patients $(78,4 \%)$. In patients with herpetic stomatitis and some children with SARS, the mucous membrane was pasty and slightly hyperemic (17 patients - 19,3\%).

The mucous membrane at the mouth of the excretory ducts of the glands involved in inflammation was swollen in all patients, hyperemic in 66 cases $(75 \%)$, and in 37 patients (42\%) the mouth was radiated. When massaging the glands from the ducts, all patients were given a viscous secret with impurities of whitish flakes of different sizes in different amounts and purulent «plugs» (Fig. 2).

The clinical and laboratory characteristics of patients with chronic parenchimatic parotitis in remission period were examined on the basis of examination of the same group of children, which was formed during the treatment of exacerbation of inflammation in parotid glands. It was carried out 6 months after the last exacerbation.
In the survey of 88 children at this time, 63 - $(71,6 \%)$ had no complaints. The examination and palpation of the parotid glands were within the normal range, were mild and painless. The other 25 patients $(28,4 \%)$ complained of low-intensity pain, most commonly associated with food intake and periodic slight swelling of the affected glands. Examination of these children revealed a pronounced localized swelling of the soft tissues in the location of the parotid glands, which was due to the presence of infiltrative changes in separate lobes of the gland. In 65 children (74\%) it was found out a slight increase in regional lymph nodes on the side of the parotid gland involved in chronic inflammation. The skin over their projection was unchanged and easily folded.

The oral mucosa had a pale pink color and was well moisturized in all patients, however, in 21 children (23,9\%), the oral fluid was high in viscosity, foamy, and had a salty taste. The 
mucous membrane at the mouth of the excretory ducts of the affected glands was swollen in 33 children (37,5\%), the crown of hyperemia around the mouth was determined in 19 patients $(21,6 \%)$, and in $17-(18,3 \%)$ the mouth remained gaping.

When massaging the glands from the ducts, 62 patients $(70,5 \%)$ exhibited a viscous secret, 43 of them (69\%) identified single small whitish flakes. The secret was transparent in $11 \mathrm{pa}-$ tients $(12,5 \%)$ and was not received at all in 8 patients $(9,1 \%)$.

\section{CONCLUSIONS}

Thus, in children with chronic parenchimatic parotitis, the presence of pathological conditions in their mothers during pregnancy exceeds the control indexes by 3,5 times, and the disturbance of childbirth was observed more than 3,3 times, which required additional maternity measures. Only $36 \%$ of children were in natural feeding for a year, and among those who were mixed and artificially nourished, the number of sick people was 2 times higher than in the comparison group. Exacerbation in software in $91 \%$ of children was triggered or coincided with acute infectious processes, or with exacerbation of chronic somatic diseases, which caused the clinical severity of their combined effect on the general condition and manifestations of inflammation directly in the glands themselves. During the remission period, the explicit clinical data on the presence of the chronic process were not determined in $72 \%$ of the observations, but in the other $28 \%$, a detailed in-depth examination revealed signs indicating a hidden course of inflammation in the parotid glands.

Prospects for further developments in this direction. Establishing cooperation with pediatricians and specialists in related profiles will reduce the frequency of exacerbations of chronic parenchimatic parotitis and extend the remission period.

\section{REFERENCES}

1. Tkachenko P.I., Starchenko I.I., Bilokon S.0. et al. Dobroiakisni novoutvorennia miakykh tkanyn shchelepno-lytsevoi dilianky ta slynnykh zaloz u ditei [Malignant neoplasms of soft tissues of maxillofacial area and salivary glands in children]. Poltava: TOV «ASMl»; 2015. 80. (UK)

2. Tkachenko P.I., Starchenko I.I., Bilokon S.0. et al. Nespetsyfichni limfadenity shchelepno-lytsevoi dilianky u ditei (kliniko-morfolohichni aspekty [Non-specific lymphadenitis of the maxillofacial area in children (clinical and morphological aspects)]. VDNZU «UMSA».- Poltava: TOV «ASMl»; 2018. 120. (UK)

3. Tkachenko P.I., Popelo Yu.V., Bilokon S.O. Reaktsiia pryvushnykh zaloz i bukal'noho epiteliiu u ditei zi zloyakisnymy pukhlynamy cherevnoi porozhnyny na tli otrymannia khimioterapii [Response of parotid glands and buccal epithelium in children with malignant tumors of the abdomen against receiving chemotherapy]. Svit medytsyny ta biolohii. 2017; 1(59): 83-87. (UK)

4. Tkachenko P.I., Popelo Yu.V. Korektsiia sekretornoi aktyvnosti slynnykh zaloz ta yakisnykh vlastyvostei rotovoi ridyny u ditei zi zloiakisnymy pukhlynamy cherevnoi porozhnyny yaki otrymuiut' tsytostatychni preparaty [Correction of secretory activity of salivary glands and qualitative properties of oral fluid in children with malignant tumors of the abdominal cavity receiving cytostatic drugs]. Svit medytsyny ta biolohii. 2016;1 (55):88-92. (UK)
5. Tkachenko P.I., Bilokon S.0., Lokhmatova N. et al. Statystychni vidomosti pro zapal'ni protsesy shchelepno-lytsevoi dilianky u ditei [Statistics on inflammatory processes of the maxillofacial area in children]. Wiad. Lek. 2018;3(II):621-624. (UK)

6. Tkachenko P.I., Korotych N.M., Lokhmatova N.M. Ekonomichnyi efekt vid zastosuvannia riznykh likuval'nykh skhem u ditei z hostrym zapal'nymy protsesamy shchelepno-lytsevoi dilianky ta khronichnym parenkhimatoznym parotytom [The economic effect of the use of various therapeutic regimens in children with acute inflammatory processes of the maxillofacial area and chronic parenchimatic parotitis]. Svit medytsyny ta biolohii. 2015; 1(48): 77-80. (UK)

7. Tkachenko P.I. Belokon S.A., Dobroskok V.A. et al. Informativeness of ultrasonography and sialodenography in active clinical course of chronic parenchymatous parotitis in children. The new Armenian medical journal. 2017;11(3):37-42.

8. Tkachenko P.I., Dobroskok V.0., Korotych N.M. et al. The role of microbial component in the progression of the acute suppurative inflammation of tissues of maxillofacial area in children. Svit medytsyny ta biolohii. 2018;1(63):83-86.

9. Tkachenko P.I., Lokhmatova N.M., Korotych N.M. Kompleksne likuvannia zahostrennia khronichnoho parenkhimatoznoho parotytu u ditei, neaktyvnyi perebih [Complex treatment of exacerbation of chronic parenchimatic parotitis in children, inactive course].Visnyk problem biolohii i medytsyny.2014; 2(44):83-87. (UK)

The paper is written within the research study entitled "Integrative-and-differential substantiation of the choice of optimal methods of surgical interventions and the scope of therapeutic activities in the surgical pathology of the maxillofacial area" (State Registration No. 0116U003821).

\section{ORCID and contributorship:}

Pavlo I. Tkachenko - 0000-0001-5734-8137 A,B,C,F

Serhii O. Bilokon - 0000-0002-7800-0516 A,D,F

Yuliia V. Popelo - 0000-0003-0002-366 ${ }^{A, E, F}$

Nataliia M. Lokhmatova - 0000-0002-7800-0516 ${ }^{E, F}$

Olha B. Dolenko - 0000-0002-7264-4206 E,F

Nataliia M. Korotych - 0000-0003-1893-2554 E,F

\section{Conflict of interest:}

The Authors declare no conflict of interest.

\section{CORRESPONDING AUTHOR \\ Yuliia V. Popelo}

Ukrainian Medical Stomatological Academy

St. Shevchenko, 23., , Poltava, Ukraine

tel: +380664603303

e-mail: yulia.kit71@gmail.com

Received: 01.03 .2020

Accepted: 07.05 .2020 